\title{
Coconut mealybug Nipaecoccus nipae (Maskell)(Insecta: Hemiptera: Pseudo coccidae) ${ }^{1}$
}

Adriana Espinosa, Amanda Hodges, Greg Hodges, and Catharine Mannion²

\section{Introduction}

The coconut mealybug, Nipaecoccus nipae (Maskell), is also called the spiked mealybug, nipa mealybug, avocado mealybug, sugarapple mealybug or Kentia mealybug. The several names are due to the wide host range of this pest, but coconut mealybug is the most widely used common name. Coconut mealybug may be economically damaging to palms and tropical fruit crops.

\section{Distribution}

This mealybug is widely distributed. It has been found in North, Central and South America; Europe, Asia, Oceania and Africa (Miller et. al. 2007).

\section{Field Characteristics}

The adult female is generally the best life stage for identification. Final, confirmatory species-level identification of a mealybug is often based on slide-mounted morphological features associated with adult females.

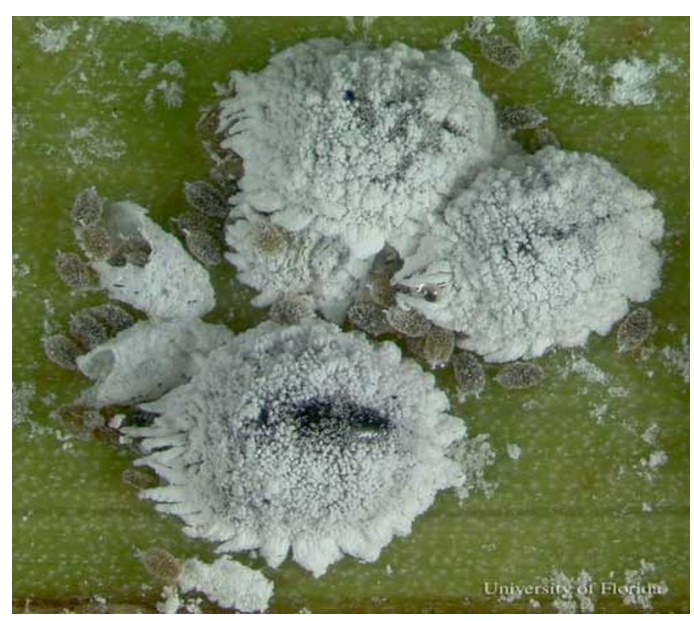

Figure 1. Adults and immatures of the coconut mealybug, Nipaecoccus nipae (Maskell). Credits: Lyle J. Buss, University of Florida

Adult females range between 0.059 and 0.98 inches (1.5 and $2.5 \mathrm{~mm}$ ) long, are oval in shape and reddish-brown to orange in color, covered by a yellowish-orange thick wax and with 10 to 12 pairs of marginal pyramid-shaped wax filaments. The dorsal surface of the body contains five to eight waxy filaments similar to the ones present on the side or

1. This document is EENY-448, one of a series of Featured Creatures from the Entomology and Nematology Department, Florida Cooperative Extension Service, Institute of Food and Agricultural Sciences, University of Florida. Published: June 2009. This document is also available on Featured Creatures Web site at http://creatures.ifas.ufl.edu. Please visit the EDIS Web site at http://edis.ifas.ufl.edu. Additional information on these organisms, including many color photographs, is available at the Entomology and Nematology Department website at http://entnemdept.ifas.ufl.edu/.

2. Adriana Espinosa, former extension assistant; Amanda Hodges, assistant extension scientist, Department of Entomology and Nematology; Gregg Hodges, courtesy assistant professor, Department of Entomology and Nematology; Catharine Mannion, associate professor, Department of Entomology and Nematology, Tropical Research and Education Center (REC)--Homestead FL; Florida Cooperative Extension Service, Institute of Food and Agricultural Sciences, University of Florida, Gainesville, FL 32611.

The Institute of Food and Agricultural Sciences (IFAS) is an Equal Opportunity Institution authorized to provide research, educational information and other services only to individuals and institutions that function with non-discrimination with respect to race, creed, color, religion, age, disability, sex, sexual orientation, marital status, national origin, political opinions or affiliations. U.S. Department of Agriculture, Cooperative Extension Service, University of Florida, IFAS, Florida A. \& M. University Cooperative Extension Program, and Boards of County Commissioners Cooperating. Millie Ferrer, Interim Dean. 
lateral areas of the body. No ovisac or egg-containing sac within the female is present.

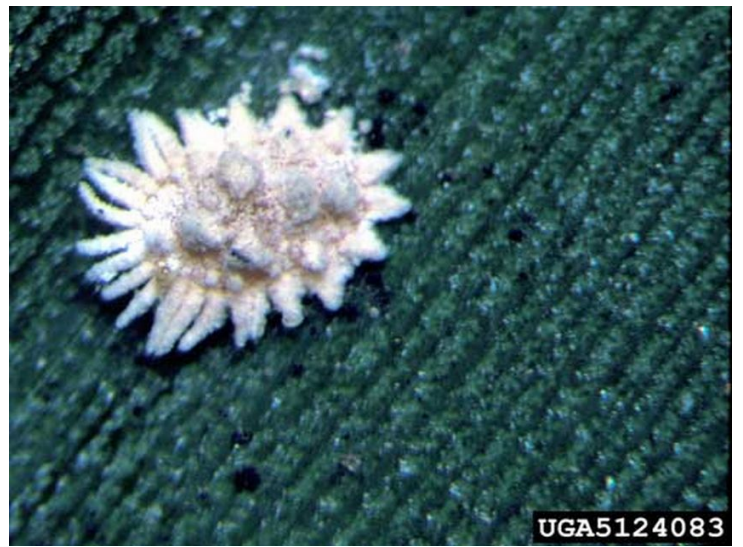

Figure 2. Adult female coconut mealybug, Nipaecoccus nipae (Maskell), feeding on bird-of-paradise. Notice the five to eight dorsal, waxy filaments similar to the ones present on the side or lateral areas of the body. Credits: Raymond Gill, California Department of Food and Agriculture; www.insectimages.org

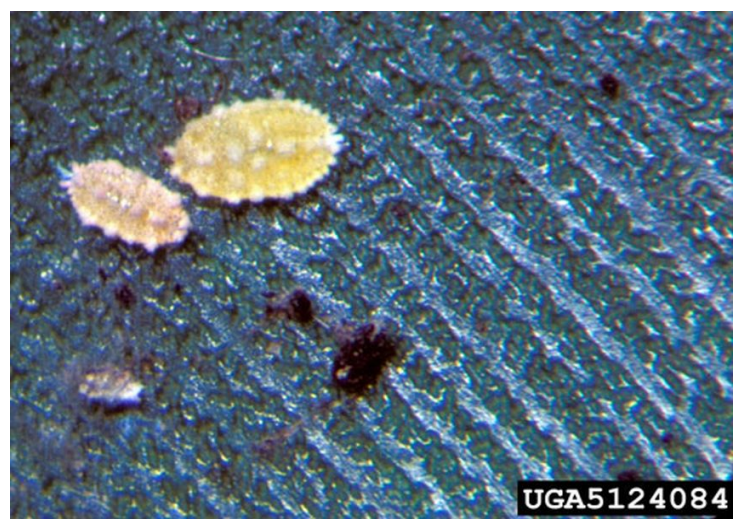

Figure 3. Nymphs of the coconut mealybug, Nipaecoccus nipae (Maskell), feeding on bird-of-paradise. Notice the thick yellowish-orange wax. Credits: Lyle J. Buss, University of Florida

Males are oblong and smaller than females. Males develop in very thin white cottony wax cocoons prior to emerging as adults (Hodges et.al. 2008, Miller et. al. 2007).

\section{Life Cycle}

Males and females cannot be readily distinguished from each other during the first two instars, but the third instar female begins to resemble the adult. When present, immature males change within a pupal cocoon during the third instar prior to emerging as a winged adult.

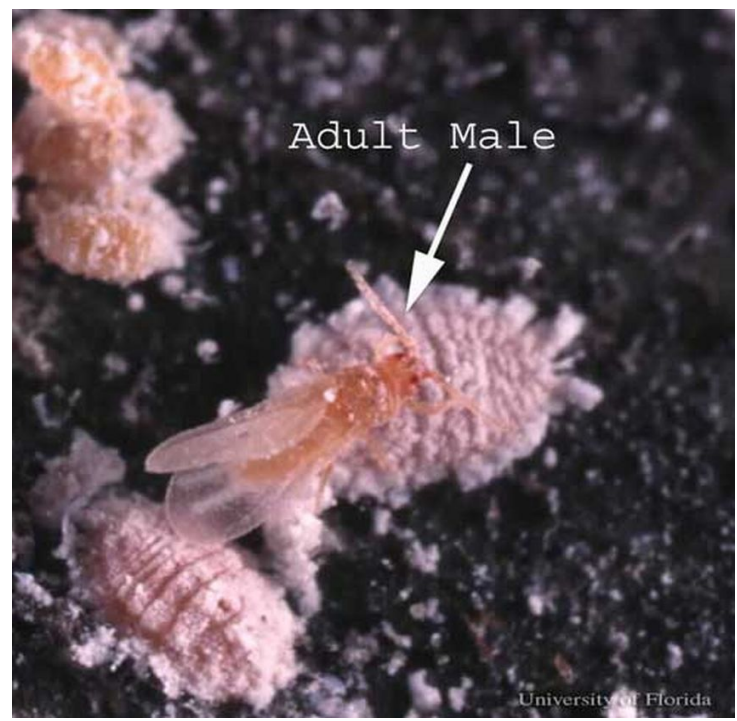

Figure 4. Adult female (center) and male (arrow) of the coconut mealybug, Nipaecoccus nipae (Maskell). Immature coconut mealybugs appear in the upper left. Credits: Lyle J. Buss, University of Florida

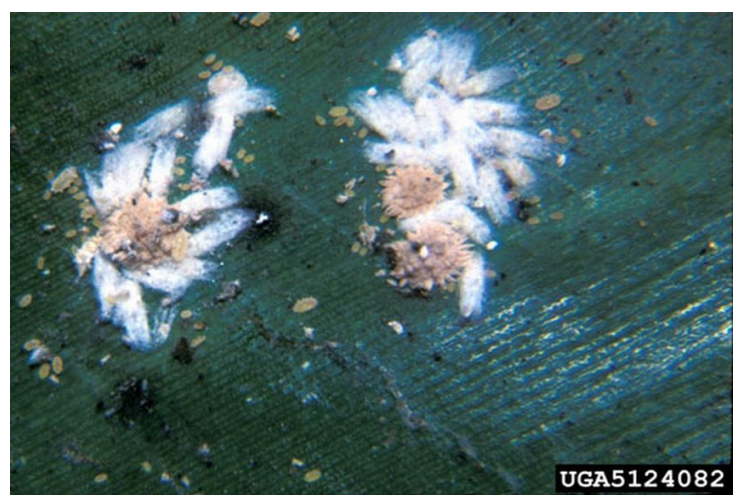

Figure 5. The life cycle of the coconut mealybug, Nipaecoccus nipae (Maskell), is shown on stages appearing on bird-of-paradise. Small first and second instar nymphs are scattered around the image. Larger, reddish-brown, third instar females are seen surrounded by the thin, white cottony wax cocoons of the third instar males. Credits: Lyle J. Buss, University of Florida

\section{Hosts}

This species attacks more than 40 families of host plants, including:

- Agavaceae - Dracaena spp.

- Heliconiaceae - Heliconia spp.

- Lauraceae - Persea americana (avocado)

- Musaceae - Musa spp. (banana) 
- Orchidiaceae - (orchids)

- Palmae - including: sago palm, Cycas revoluta; pygmy palm, Phoenix roebelenii; California fan palm, Washingtonia filifera; parlor palm, Chamaedorea elegans; Queen palm, Syagrus romanzoffianum; Ketina palm, Howea spp.; lady palm, Raphis spp.; and Washington palm, Washington robusta

- Rubiaceae - Coffea spp.

- Rutaceae - Citrus spp.

- Solnaceae - Solanum tuberosum (potato)

- Vitaceae - Vitis spp. (grape)

-Zingiberaceae - Zingiber spp. (ginger)

-(Gilman and Watson 2007, Miller et. al. 2007).

\section{General Plant Damage}

Adult females and immatures feed on the sap of the host plant. Honeydew secretions produced during feeding may result in black, sooty mold growth. The presence of sooty mold can result in reduced photosynthesis, defoliation, and occasional death of a young plant (Watson 2004). Ants are often found feeding on mealybug honeydew secretions and may also defend the mealybugs from predators or parasitoids (Ben-Dov 1994, Williams and Granara de Willink 1992).

\section{Management}

Management of scale and mealybug insects begins with detection and identification of the pest. Mealybugs can be very small or resemble disease organisms or even plant structures, making detection difficult. Regular monitoring will allow detection of these pests before damage is obvious and will also allow improved control. All plant parts need to be searched, including the undersides of leaves and stems. Inspection of plants prior to introducing them into the landscape, nursery or collection is very important in reducing new infestations of scales.

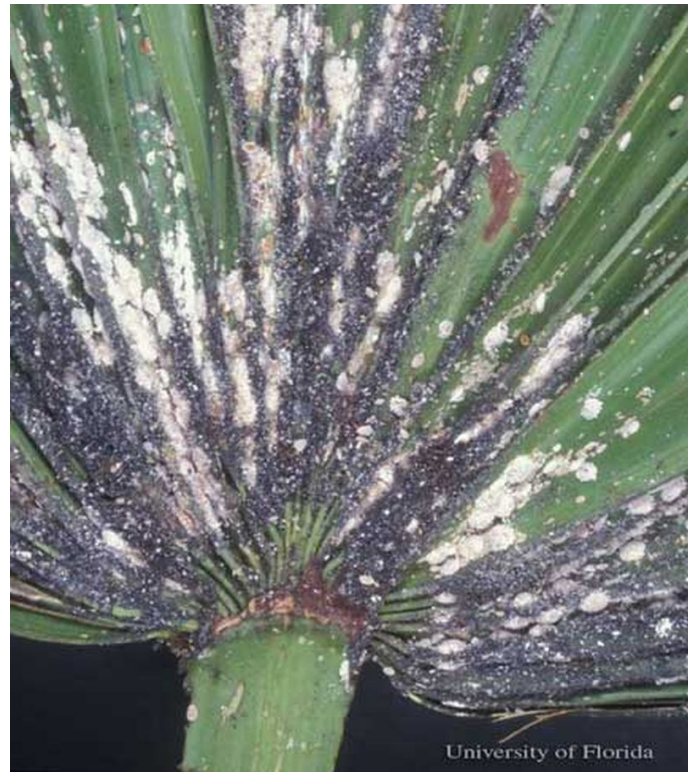

Figure 6. An infestation of the coconut mealybug, Nipaecoccus nipae (Maskell), on a palm species. Black sooty mold growth is common with high populations. Credits: Lyle J. Buss, University of Florida

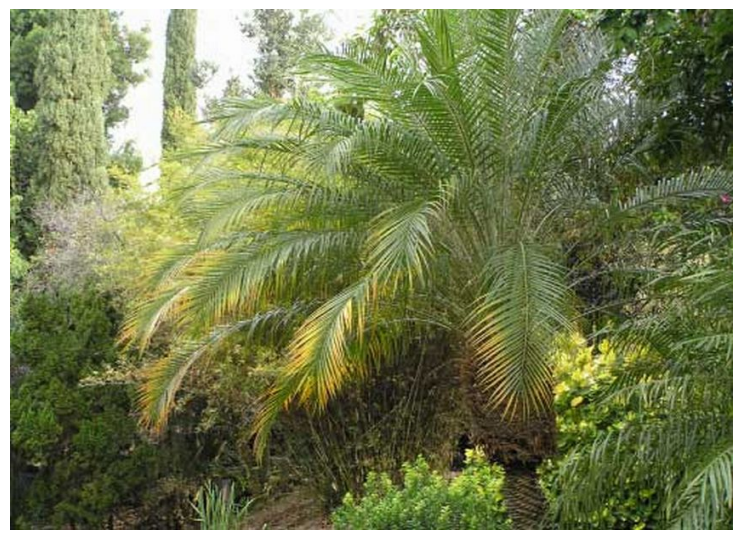

Figure 7. Frond yellowing caused by an infestation of the coconut mealybug, Nipaecoccus nipae (Maskell), on pygmy date palm. Credits: Scot Nelson and Mike Nago, University of Hawaii at Manoa

Management can be difficult because of the waxy material mealybugs produce which provides protection from many insecticides. Pruning or washing infested plant parts can be helpful in reducing populations, particularly in cases of small infestations. A brisk wash spray of water can also be helpful in removing mealybugs from plants and reducing the population. Mealybugs are commonly attacked by predators, parasites and diseases which can help manage populations, particularly for long term control. It is important to recognize the presence of beneficial insects and to take steps to conserve them in the environment so they are available to 


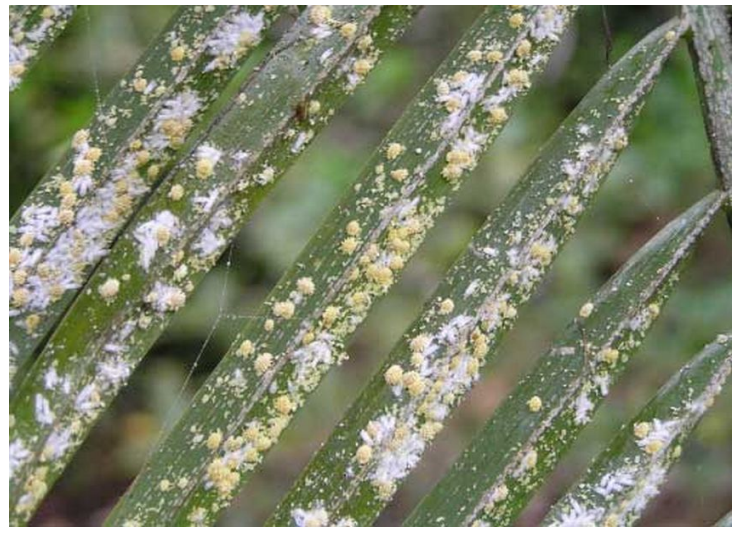

Figure 8. Infestation of the coconut mealybug, Nipaecoccus nipae (Maskell), on pygmy date palm. Credits: Scot Nelson and Mike Nago, University of Hawaii at Manoa

control the pest insects. The use of Pseudaphycus utilis Timberlake, a parasitic wasp, as a biological control agent successfully controlled coconut mealybug in Hawaii and Puerto Rico (Watson 2004).

It is often necessary to manage mealybugs with insecticides so it is important to select appropriate insecticides, timing and application methods to reduce negative impact on the natural enemies but still get maximum control.

Contact insecticides commonly provide quick knockdown of the pest but require good coverage and generally repeat applications. The stage most susceptible to contact insecticides is the crawler stage.

Horticultural oil and insecticidal soaps also can provide good control, but must be treated like contact insecticides, which require thorough coverage and repeat applications.

Systemic insecticides can provide excellent options for scale control and can provide some flexibility in application timing and methods. These insecticides move through the plant and provide an excellent way to expose scale insects to the insecticide when they feed on the plant.

It is important not to overuse or misuse insecticides which can lead to numerous problems including insecticide resistance. To avoid insecticide resistance it is critical to rotate among insecticide groups.
Florida Insect Management Guide for scale insects and mealybugs on ornamental plants

Florida Citrus Pest Management Guide: soft-bodied insects attacking foliage and fruit

\section{Selected References}

Ben-Dov Y. 1994. A Systematic Catalogue of the Mealybugs of the World (Insecta: Homoptera: Coccoidea: Pseudococcidae and Putoidae) with Data on Geographical Distribution, Host Plants, Biology and Economic Importance. Intercept Limited, Andover, UK. 686 pp.

Buss EA,Turner JC. (June 2006). Scale Insects and Mealybugs on Ornamental Plants. EDIS. http://edis.ifas.ufl.edu/MG005 (4 May 2009).

Gilman EF, Watson DG. (April 2007). Washington robusta: Washington palm. EDIS. http://edis.ifas.ufl.edu/ST670 (4 May 2009).

Hodges A, Hodges G, Buss L, Osborne L. (2008). Mealybugs and mealybug look-alikes of the Southeastern United States. North Central IPM Center. http://www.ncipmc.org/alerts/phmb/mealybugs.pdf (4 May 2009).

Miller DR, Rung A, Venable GL, Gill RJ. (August 2007). Scale Insects: Identification tools, images, and diagnostic information for species of quarantine significance. Systematic Entomology Laboratory USDA-ARS. http://www.sel.barc.usda.gov/scalekeys/ ScaleInsectsHome/ScaleInsectsHome.html (4 May 2009).

Rosen D. (July 2005). Adult females, nymphs, and waxy egg mass of coconut mealybug, Nipaecoccus nipae. UC IPM Online. http://www.ipm.ucdavis.edu/PMG/N/I-HO-NNIPCO.001.html (4 May 2009).

Watson G. (July 2007). Invasive Insect Report 2004.06. Coconut mealybug Nipaecoccus nipae (Homoptera: Pseudococcidae). University of Guam Cooperative Extension Service Knowledgebase Wiki. http://guaminsects.net/uogces/kbwiki/ index.php?title=IRR2004.06 (4 May 2009). 
Williams DJ., Granara de Willink, MC. 1992.

Mealybugs of Central and South America. CAB

International, London, England. 635 pp. 